\title{
Separation and Determination of Fe(III) and Fe(II) in Natural and Waste Waters Using Silica Gel Sequentially Modified with Polyhexamethylene Guanidine and Tiron
}

\author{
Svetlana Didukh, ${ }^{1}$ Vladimir Losev, ${ }^{1}$ Elena Borodina, ${ }^{1}$ Nikolay Maksimov, ${ }^{2}$ \\ Anatoly Trofimchuk, ${ }^{3}$ and Olga Zaporogets ${ }^{3}$ \\ ${ }^{1}$ Scientific Research Engineering Centre "Kristall", Siberian Federal University, Krasnoyarsk, Russia \\ ${ }^{2}$ Institute of Chemistry and Chemical Technology, Siberian Branch, Russian Academy of Sciences, Krasnoyarsk, Russia \\ ${ }^{3}$ Taras Shevchenko National University of Kyiv, Kyiv, Ukraine \\ Correspondence should be addressed to Svetlana Didukh; semdid@mail.ru
}

Received 27 June 2017; Accepted 12 September 2017; Published 31 October 2017

Academic Editor: Krishna K. Verma

Copyright (C) 2017 Svetlana Didukh et al. This is an open access article distributed under the Creative Commons Attribution License, which permits unrestricted use, distribution, and reproduction in any medium, provided the original work is properly cited.

\begin{abstract}
Silica gel, sequentially modified with polyhexamethylene guanidine and pyrocatechin-3,5-disulfonic acid (Tiron), was suggested for sorption separation and determination of $\mathrm{Fe}$ (III) and $\mathrm{Fe}$ (II). It was found that quantitative extraction of $\mathrm{Fe}$ (III) and its separation from $\mathrm{Fe}(\mathrm{II})$ were attained at $\mathrm{pH}$ 2.5-4.0, while quantitative extraction of $\mathrm{Fe}(\mathrm{II})$ was observed at $\mathrm{pH}$ 6.0-7.5. An intensive signal with $g=4.27$, which is characteristic for Fe(III), appeared in EPR spectra of the sorbents after Fe(II) and Fe(III) sorption. During interaction between Fe(II) and Tiron, fixed on the sorbent surface, its oxidation up to Fe(III) occurred. Red-lilac complexes of the composition $\mathrm{FeL}_{3}$ were formed on the sorbent surface during sorption regardless of initial oxidation level of iron. Diffuse reflectance spectrum of surface complexes exhibited wide band with slightly expressed maxima at 480 and $510 \mathrm{~nm}$. Procedures for separation and photometric determination of $\mathrm{Fe}(\mathrm{III})$ and $\mathrm{Fe}(\mathrm{II})$ at the joint presence and total $\mathrm{Fe}$ content determination as $\mathrm{Fe}$ (II) in waste and natural waters was developed. The limit of detection for iron was $0.05 \mu \mathrm{g}$ per $0.100 \mathrm{~g}$ of the sorbent. The calibration graph was linear up to $20.0 \mu \mathrm{g}$ of Fe per $0.100 \mathrm{~g}$ of the sorbent. The RSD in the determination of more than $0.2 \mu \mathrm{g}$ of Fe was less than 0.06 .
\end{abstract}

\section{Introduction}

Element speciation, including determination of various oxidation states of the elements, in environmental objects is an important challenge of analytical chemistry. Iron refers to bioactive metals and plays an important biological role in plants, animals, and human beings. Natural waters contain iron in oxidation states +2 and +3 , and $\mathrm{Fe}$ (III) content is much higher than $\mathrm{Fe}$ (II) content at that.

Photometric methods of analysis are the most widely used methods for determination of iron in various oxidation states $[1,2]$; they are highly sensitive and selective. Organic reagents used in photometric methods form complex compounds with either $\mathrm{Fe}(\mathrm{III})$ or $\mathrm{Fe}(\mathrm{II})$. The best known organic reagents for the photometric determination of $\mathrm{Fe}(\mathrm{II})$ are $\mathrm{N}$-heterocyclic bases: 1,10-phenantroline and 2,2' -dipyridyl [2]. Sulfosalicylic acid and Tiron [3] are the most widely used photometric reagents for $\mathrm{Fe}(\mathrm{III})$ determination.

Some reagents-derivatives of di-2-pyridyl ketone hydrazone: di-2-pyridyl ketone benzoylhydrazone and di-2-pyridyl ketone salicyloylhydrazone $[4,5]$ are known to form complex compounds with both $\mathrm{Fe}(\mathrm{II})$ and $\mathrm{Fe}(\mathrm{III})$. Detection of $\mathrm{Fe}(\mathrm{II})$ is carried out at one wavelength, and then the other wavelength is used for determination of the total iron content; $\mathrm{Fe}(\mathrm{III})$ content is calculated as a difference between total iron and $\mathrm{Fe}(\mathrm{II})$ content.

The following approaches are used for the photometric determination of $\mathrm{Fe}(\mathrm{II})$ and $\mathrm{Fe}(\mathrm{III})$ in one sample.

The first one is based on the application of the reagents which form complex compounds with $\mathrm{Fe}$ (II) or $\mathrm{Fe}(\mathrm{III})$. In this case, if the reagent forming complexes with $\mathrm{Fe}(\mathrm{II})$ is applied, the concentration of $\mathrm{Fe}(\mathrm{III})$ is calculated as a difference 
between total iron (after reduction of Fe(III) to Fe(II) using ascorbic acid, hydroxylamine, or reductor minicolumn) and $\mathrm{Fe}(\mathrm{II})$ content. If the reagent forming complexes with $\mathrm{Fe}(\mathrm{III})$ is applied, concentration of $\mathrm{Fe}(\mathrm{II})$ is calculated as a difference between total iron (after oxidation of $\mathrm{Fe}(\mathrm{II})$ to $\mathrm{Fe}$ (III) using hydrogen peroxide) and $\mathrm{Fe}(\mathrm{III})$ content $[3,6-8]$.

The second approach is based on the application of two chelating reagents, one of which is selective to $\mathrm{Fe}(\mathrm{II})$ and the other one is selective to Fe(III). For example, spectrophotometric sequential injection system was proposed for simultaneous determination of $\mathrm{Fe}$ (II) and $\mathrm{Fe}$ (III) based on introduction of reagents (1,10-phenanthroline and sulfosalicylic acid) into a stream of samples. The subsequent introduction of EDTA into a stream resulted in decomposition of $\mathrm{Fe}$ (III) compound with sulfosalicylic acid and absorption of $\mathrm{Fe}$ (II) compound with 1,10-phenanthroline was measured [9]. Fe(III) and Fe(II) were separated by silica microcolumn ion chromatography and determined via complexation with salicylic acid and 1,10-phenanthroline, respectively [10]. Capillary zone electrophoresis was applied for the simultaneous determination of iron(II) and iron(III) selectively complexed with 1,10-phenanthroline and transcyclohexane-1,2-diaminetetraacetic acid [11].

The third approach is based on different optical characteristics or different rates of formation of colored complexes of $\mathrm{Fe}(\mathrm{II})$ and $\mathrm{Fe}(\mathrm{III})$ with some organic reagents, for example, gallic acid [12] or Tiron [13].

Organic reagents are used in the combination of various methods of separation and determination of $\mathrm{Fe}(\mathrm{II})$ and $\mathrm{Fe}(\mathrm{III})$. Two-line manifold flow injection system with optoelectrochemical detection was used for separate determination of $\mathrm{Fe}(\mathrm{II})$ and $\mathrm{Fe}(\mathrm{III})$ [14]. Fe(III) was determined using photometric method as complex compound with sulfosalicylic acid, and Fe(II) was determined using electrochemical method. Method of separate determination of $\mathrm{Fe}$ (II) and Fe(III) using atomic absorption spectroscopy was suggested. Method is based on sorption separation of $\mathrm{Fe}(\mathrm{II})$ as its complex with ferrozine on a $\mathrm{C}_{18}$-modified silica column and direct atomic absorption determination of $\mathrm{Fe}(\mathrm{III})$ in solution passed through the column; then, Fe(II) was determined in eluate after desorption of iron(II)-ferrozine complex using atomic absorption spectroscopy [15].

Photometric method is used in coupling with sorption preconcentration in order to improve its sensitivity and selectivity. Iron may be determined directly in the sorbent phase [16-21] or in the solution after desorption [22-24]. Sorbents based on ion-exchange resins [16-18], polymethacrylate matrixes [20], silica $[19,24]$, cellulose [22], and naphthalene [23] are suggested.

Colorless sorbents are preferred to be used for sorptionphotometric determination of Fe(III) and Fe(II). From this point of view silica based sorbents modified with colorless organic reagents which can form colored complexes with iron ions are very promising. Examples of such reagents include Tiron (4,5-dihydroxybenzene-1,3-disulfonic acid), which forms colored complex compounds with Fe(III) [25, 26].

Sorption of Fe(III) complexes with Tiron from aqueous solutions using ion-exchange resin AV-17 was studied in [27].
$\mathrm{Fe}(\mathrm{III})$ forms complex with Tiron in solution at $\mathrm{pH}$ of 3.5-9.0 and $\mathrm{Fe}(\mathrm{II})$ - at $\mathrm{pH}$ of 6.0-9.0; this phenomenon was used for sorption-photometric determination of $\mathrm{Fe}$ (III) at $\mathrm{pH}$ of 3.5 , and the total content of $\mathrm{Fe}$ (II) and $\mathrm{Fe}$ (III) was determined at $\mathrm{pH}$ of 6-9.

At the present work silica gel sequentially modified with polyhexamethylene guanidine and Tiron was suggested for sorption separation and sorption-photometric determination of Fe(III) and Fe(II). Procedures for separate sorptionphotometric determination of $\mathrm{Fe}$ (III) and $\mathrm{Fe}$ (II) from one sample of water and sorption-photometric and test-method for determination of the total iron content as Fe(II) in natural waters were developed.

\section{Experimental}

2.1. Reagents and Chemicals. All reagents were of analytical grade. Deionized water was used for the preparation of the solutions.

A stock standard solutions of $\mathrm{Fe}$ (III) and $\mathrm{Fe}(\mathrm{II})$ $\left(100 \mathrm{mg} \mathrm{L}^{-1}\right)$ were prepared by dissolving of $\mathrm{FeSO}_{4}$ and $\mathrm{Fe}_{2}\left(\mathrm{SO}_{4}\right)_{3}$ in $0.1 \mathrm{M} \mathrm{H}_{2} \mathrm{SO}_{4}$. Working solutions with lower concentrations were prepared by dilution of stock solution with deionized water immediately prior to use.

The required $\mathrm{pH}$ was adjusted by adding $\mathrm{HCl}, \mathrm{NaOH}$, or acetic buffer solution ( $\mathrm{pH} 4.0-6.5)$ and ammonium chloride buffer solution ( $\mathrm{pH}$ 7.5-9.0). Hydroxylamine hydrochloride $(0.1 \mathrm{M}$ solution) was used in order to reduce $\mathrm{Fe}$ (III) into $\mathrm{Fe}(\mathrm{II})$.

Silica gel Silokhrom S-120 (fraction of 0.1-0.2 mm, specific surface area $\sim 120 \mathrm{~m}^{2} \mathrm{~g}^{-1}$, and average pore diameter $\sim 45 \mathrm{~nm}$ ) was used as a matrix for the sorbent synthesis.

Stock solution of polyhexamethylene guanidine hydrochloride (PHMG) (7.5\% w/w solution) was prepared by dissolving weighted portion of BIOPAG-D reagent (Institute of Ecotechnological problems, Moscow, Russian Federation) in deionized water.

A 0.016 M Tiron stock solution was prepared by dissolving accurately weighted portion of the reagent in deionized water. Solutions with lower concentrations were prepared by dilution of the initial solution with deionized water.

2.2. Apparatus. Diffuse reflectance spectra (DRS) over the range of 380-720 $\mathrm{nm}$ were registered using Pulsar Spectrophotocolorimeter (Himavtomatika, Russia). Spectra were plotted against coordinates calculated using the KubelkaMunk function; that is, $F(R)=(1-R)^{2} / 2 R$ is wavelength (nm), where $R$ is diffuse reflectance coefficient.

The UV-Vis spectra and absorbancy were registered using Cary 100 Spectrophotometer (Varian, Australia). Inductively coupled plasma optical emission spectrometer Optima 5300DV (Perkin-Elmer, USA) was used to determine metal ions concentration in solutions. The EPR spectra were recorded with an Elexsys E-580 instrument (Bruker, Germany). The $\mathrm{pH}$ measurements were carried out with a SevenEasy pH Meter S20 (Mettler-Toledo, Switzerland).

Peristaltic pump Masterflex L/S (Thermo Fisher Scientific, USA) was used for pumping solutions through a minicolumn with a sorbent. 


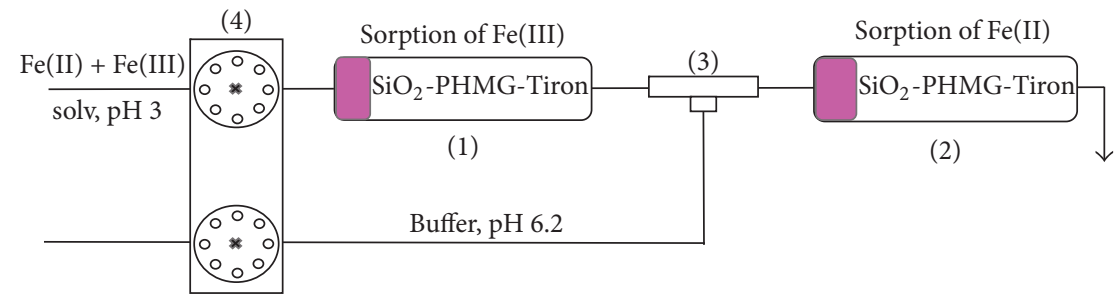

FIGURE 1: Scheme of the sorption separation of $\mathrm{Fe}(\mathrm{III})$ and $\mathrm{Fe}(\mathrm{II})$ in flow analysis using $\mathrm{SiO}_{2}$-PHMG-Tiron (minicolumn (1, 2), tee-joint (3), and peristaltic pump (4)).

2.3. Synthesis of $\mathrm{SiO}_{2}-\mathrm{PHMG}$-Tiron Sorbent. $\mathrm{SiO}_{2}-\mathrm{PHMG}$ sorbent was synthesized according to procedure described in article [28]. Weighted portions of $\mathrm{SiO}_{2}$-PHMG $(0.100 \mathrm{~g})$ were placed into test-tubes with ground stoppers, $10 \mathrm{~mL}$ of Tiron solution of appropriate concentration was added, and the tube was stirred for $5 \mathrm{~min}$. The resulting $\mathrm{SiO}_{2}-\mathrm{PHMG}-$ Tiron sorbent was separated from the solution by decantation and washed two times with deionized water. Tiron extraction was determined by the photometric analysis of water phase at the absorption band of the reagents $\lambda_{\max }=292 \mathrm{~nm}(\mathrm{pH} \mathrm{1-7)}$ and $\lambda_{\max }=297 \mathrm{~nm}(\mathrm{pH}>8)$.

2.4. Preconcentration of $\mathrm{Fe}(\mathrm{II})$ and $\mathrm{Fe}(\mathrm{III})$ by $\mathrm{SiO}_{2}-\mathrm{PHMG}^{-}$ Tiron. In the batch experiment Fe(II) or Fe(III) solution was placed into a graduated test tube with a ground stopper; $1.0 \mathrm{~mL}$ of $0.1 \mathrm{M}$ hydroxylamine solution was added (in Fe(II) sorption experiment); $\mathrm{NaOH}$, acetic ( $\mathrm{pH} 4-6$ ), or ammonium chloride $(\mathrm{pH}>7)$ buffer solution was added to adjust required $\mathrm{pH}$; and water was added to a total volume of $10.0 \mathrm{~mL}$. $\mathrm{SiO}_{2}$ PHMG-Tiron sorbent mass of $0.100 \mathrm{~g}$ was added; the tube was stopped and stirred for 1-30 minutes. The solution was decantated, the sorbent moved into the fluoroplastic cell, and diffuse reflectance coefficient was measured. The distribution of iron was controlled by the analysis of water phase using inductively coupled plasma optical emission spectroscopy (ICP-OES).

A schematic diagram of the flow analysis system is shown in Figure 1. Two minicolumns (inner diameter $3 \mathrm{~mm}$, height $50 \mathrm{~mm}$ ) $(1,2)$ each filled with $0.100 \mathrm{~g}$ of $\mathrm{SiO}_{2}$-PHMG-Tiron sorbent were connected sequentially one after another via a tee-joint (3). Solution $(20 \mathrm{~mL})$ at $\mathrm{pH} 3$ containing $1.0-5.0 \mu \mathrm{g}$ $\mathrm{Fe}(\mathrm{II})$ and $1.0-5.0 \mu \mathrm{g} \mathrm{Fe}(\mathrm{III})$ in various ratios was pumped through the first minicolumn (1) at flow rate $0.5 \mathrm{~mL} \mathrm{~min}^{-1}$ using peristaltic pump (4). Acetic buffer solution with $\mathrm{pH}$ 6.2 was introduced continuously through the tee-joint (3). The resulting solution was pumped through the second minicolumn (2). Fe(III) was sorbed in the first minicolumn at $\mathrm{pH}$ 3.0, while $\mathrm{Fe}$ (II) was passed through the first minicolumn (1) and quantitatively extracted in the second one (2) at $\mathrm{pH}$ 6.2 .

\section{Results and Discussion}

3.1. Tiron Fixation on the $\mathrm{SiO}_{2}-\mathrm{PHMG}$ Surface. Maximum recovery $(\geq 98 \%)$ of Tiron from solution of $0.16 \mathrm{mM} \mathrm{L}^{-1}$ by $\mathrm{SiO}_{2}-\mathrm{PHMG}$ sorbent was attained at $\mathrm{pH}$ of 3.0-7.5 (Figure 2,

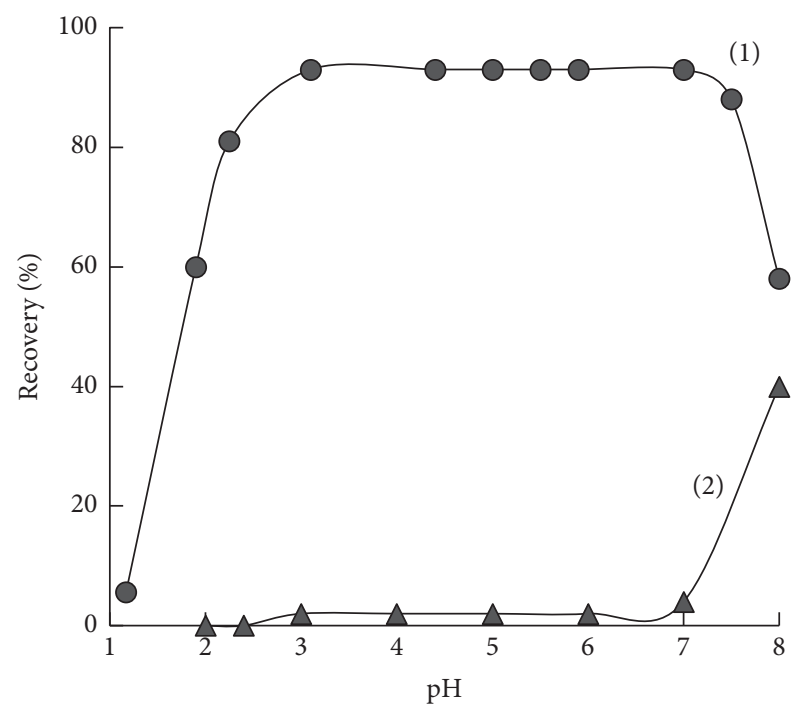

Figure 2: Recovery of Tiron (1) and catechol (2) by the $\mathrm{SiO}_{2}$-PHMG sorbent versus $\mathrm{pH}\left(C_{\text {Tiron }}=0.16 \mathrm{mM}(1,2) ; 0.100 \mathrm{~g}\right.$ of the sorbent; $V=10 \mathrm{~mL}$, contact time $10 \mathrm{~min})$.

curve (1)). The time of attainment of sorption equilibrium was less than $5 \mathrm{~min}$. Tiron fixation on the surface of $\mathrm{SiO}_{2}$ PHMG occurs due to interaction between deprotonated sulfonic groups of the reagent and positively charged amine groups of PHMG. This assumption was confirmed by comparing the recovery curves of Tiron and its unsulfonated analog-catechol versus $\mathrm{pH}$. In contrast to Tiron, catechol recovery by $\mathrm{SiO}_{2}-\mathrm{PHMG}$ sorbent (Figure 2, curve (2)) in the $\mathrm{pH}$ range of 2-7 did not exceed 1-3\%.

Maximum sorption capacity of $\mathrm{SiO}_{2}$-PHMG for Tiron was $69 \mu \mathrm{molg}^{-1}$ at $\mathrm{pH} 3.0$ and $33 \mu \mathrm{molg}^{-1}$ at $\mathrm{pH} 6.0$ (Figure 3, curves (1), (2)). The difference in sorption capacities connected with the fact that at $\mathrm{pH} 3$ Tiron sorption proceeds due to electrostatic interaction between sulfonic groups of the reagent and amine groups of PHMG fixed on the silica surface; in this case Tiron molecule is arranged perpendicular to the sorbent surface (Scheme 1(a)). At pH 6.0 Tiron fixation occurs due to both electrostatic interaction of sulfonic groups of the reagent with amine groups of PHMG and interaction of deprotonated hydroxyl groups of the reagent $\left(\mathrm{pK}_{\mathrm{a} 1}=7,7\right)$ with amine groups of PHMG, resulting in parallel arrangement of Tiron molecules to the surface of the sorbent (Scheme 1(b)). 


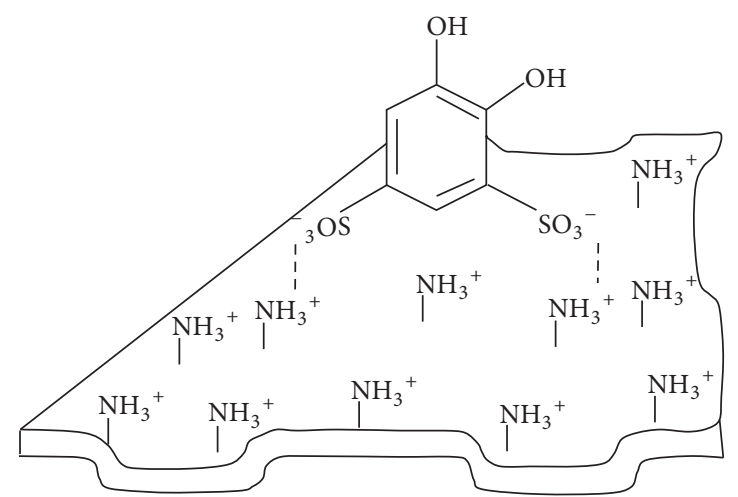

(a)

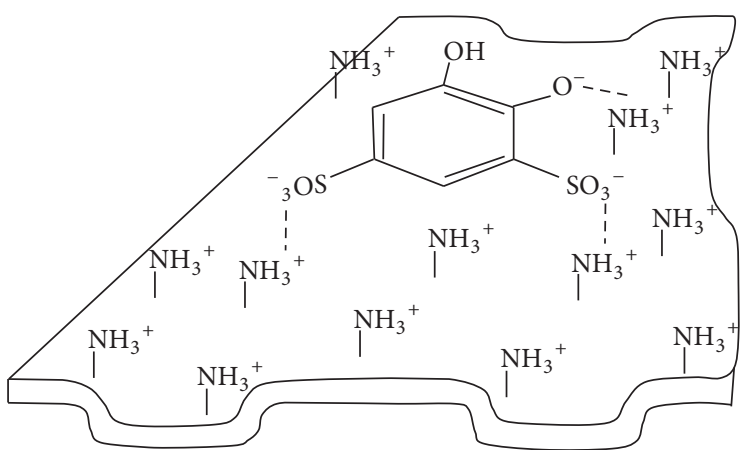

(b)

Scheme 1: Expected arrangement of the Tiron molecules on the surface of the sorbent at pH 3 (a) and pH 6.0 (b).

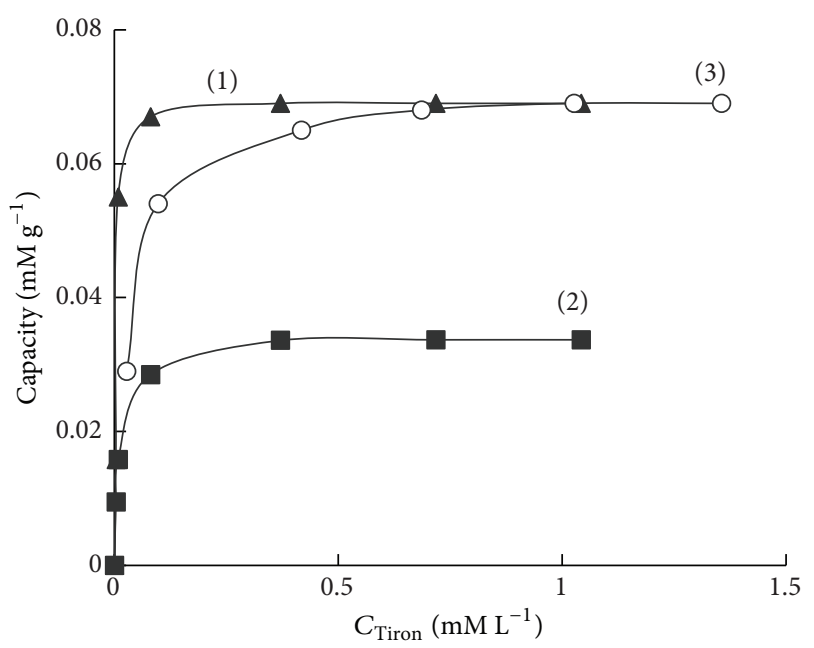

Figure 3: Sorption isotherms of $\mathrm{SiO}_{2}$-PHMG sorbent for Tiron at pH 3.0 (1), pH 6.0 (2), after sequential sorption of Tiron at $\mathrm{pH}$ 6.0, and then at $\mathrm{pH} 3.0(3)$.

This assumption is confirmed by the fact that during sequential treatment of $\mathrm{SiO}_{2}-\mathrm{PHMG}$ with Tiron solutions first at $\mathrm{pH} 6.0$ and then at $\mathrm{pH} 3.0$ an additional adsorption occurred, and total sorption capacity for Tiron was $69 \mu \mathrm{M} \mathrm{g}^{-1}$ (Figure 3, curve (3)). This value coincides with the sorption capacity of the sorbent obtained at $\mathrm{pH}$ 3.0. When passing from $\mathrm{pH} 6.0$ to $\mathrm{pH} 3.0$ changes in Tiron arrangement proceed from parallel to perpendicular against the sorbent surface; this process leads to the release of seats (amine groups of PHMG) for additional fixation of Tiron molecules.

Treatment of $\mathrm{SiO}_{2}$-PHMG-Tiron sorbent obtained at $\mathrm{pH}$ 3.0 with solutions at $\mathrm{pH} 6.0$ did not lead to the reagent desorption. This was confirmed by the absence of characteristic for Tiron absorption bands in solution.

Thus, for the sorbent with a maximum Tiron surface concentration it should be synthesized at $\mathrm{pH}$ 3.0.

Tiron fixation on the $\mathrm{SiO}_{2}$-PHMG surface is strong enough. Quantitative desorption of Tiron is achieved in $2 \mathrm{M}$

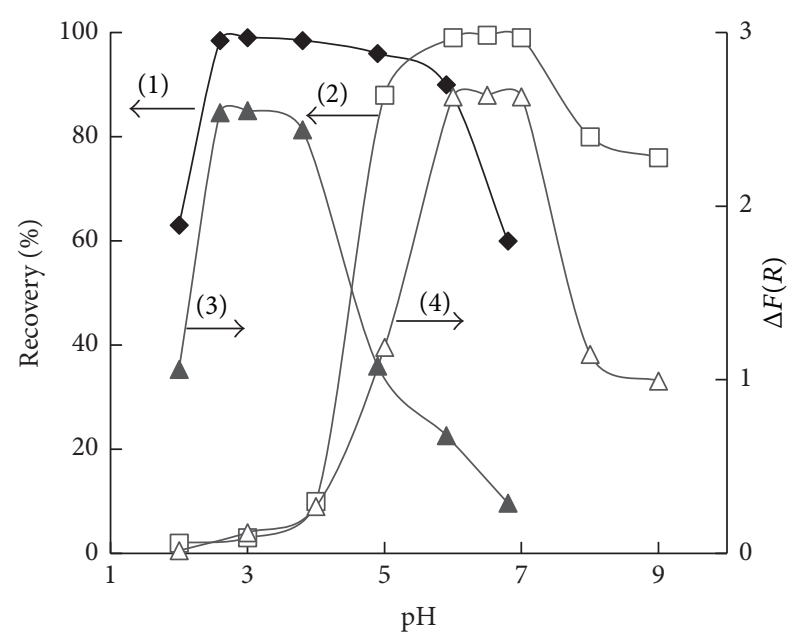

FIgure 4: Extraction of metal $\mathrm{Fe}(\mathrm{III})$ (1) and $\mathrm{Fe}(\mathrm{II})$ (2) by $\mathrm{SiO}_{2}$ PHMG-Tiron sorbent and $\Delta F(R)$ of the sorbent after sorption of $\mathrm{Fe}(\mathrm{III})(3)$ and $\mathrm{Fe}(\mathrm{II})$ (4) versus $\mathrm{pH}\left(0.100 \mathrm{~g}\right.$ of the sorbent; $C_{\text {Tiron }}=$ $\left.16 \mu \mathrm{mol} \mathrm{g}^{-1} ; C_{\mathrm{Fe}}, \mu \mathrm{g} \mathrm{mL}^{-1}: 1,0(1,2), 0,5(3,4) ; V=10 \mathrm{~mL}\right)$.

$\mathrm{HCl}$ or in highly saline solutions ( $\geq 50 \mathrm{~g} \mathrm{~L}^{-1}$ of $\mathrm{NaCl}$ ); this indirectly confirms electrostatic mechanism of fixation.

3.2. $\mathrm{Fe}(\mathrm{III})$ or $\mathrm{Fe}(\mathrm{II})$ Sorption by $\mathrm{SiO}_{2}$-PHMG-Tiron in the Batch Mode. Maximum Fe(III) recovery (98-99\%) by $\mathrm{SiO}_{2}-$ PHMG-Tiron sorbent was observed at $\mathrm{pH}$ of 2.5-4.0 and that of $\mathrm{Fe}(\mathrm{II})$ at $\mathrm{pH}$ of $6.0-7.5$ (Figure 4, curves (1), (2)). Decrease in the recovery of $\mathrm{Fe}(\mathrm{III})$ at $\mathrm{pH}>4$ was connected with its hydrolysis. Decrease in the recovery of $\mathrm{Fe}(\mathrm{II})$ at $\mathrm{pH}<6$ is coincided with conditions of its interaction with Tiron in aqueous solution. Recovery of $\mathrm{Fe}(\mathrm{II})$ at $\mathrm{pH} 3.0$ was less than 1$2 \%$. The time of attainment of sorption equilibrium of $\mathrm{Fe}(\mathrm{III})$ (at $\mathrm{pH}$ 2.5-4.0) and $\mathrm{Fe}(\mathrm{II})$ (at $\mathrm{pH}$ 6.0-7.5) extraction did not exceed $10 \mathrm{~min}$.

Sorption capacity for $\mathrm{Fe}(\mathrm{III})$ determined from the horizontal section of the sorption isotherms of $\mathrm{SiO}_{2}$ PHMG-Tiron sorbent with the surface concentration of Tiron $33 \mu \mathrm{molg}^{-1}$ and $9.2 \mu \mathrm{molg}^{-1}$ was $12 \mu \mathrm{molg}^{-1}$ and $3.6 \mu \mathrm{mol} \mathrm{g}^{-1}$, respectively (Figure 5, curves (1), (2)). Similar 


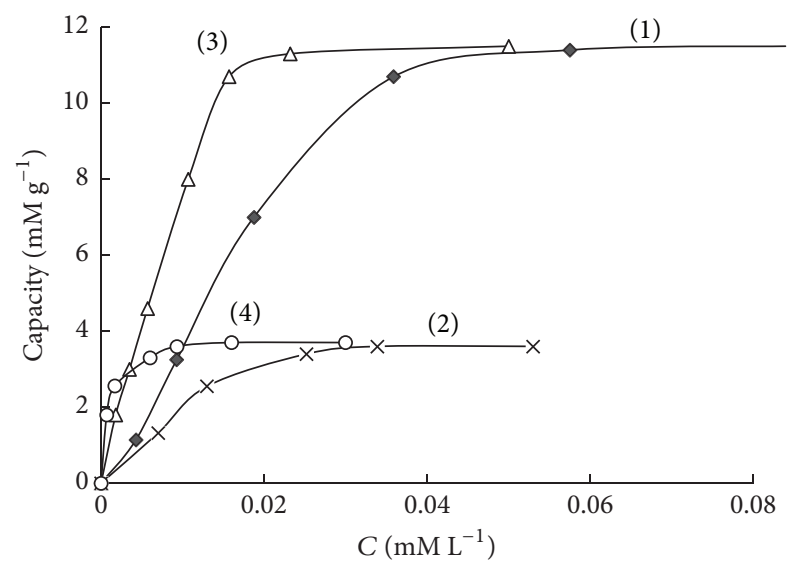

Figure 5: Sorption isotherms of $\mathrm{SiO}_{2}$-PHMG-Tiron sorbent for $\mathrm{Fe}(\mathrm{III})(1,2)$ and $\mathrm{Fe}(\mathrm{II})(3,4)\left(\mathrm{pH}: 3.0(1,2), 6.2(3,4) ; 0.1 \mathrm{M} \mathrm{NH}_{2} \mathrm{OH}\right.$ $\left.(2,4), C_{\text {Tiron }}=33(1,3), 9.2(2,4) \mu \mathrm{Mg}^{-1}\right)$.

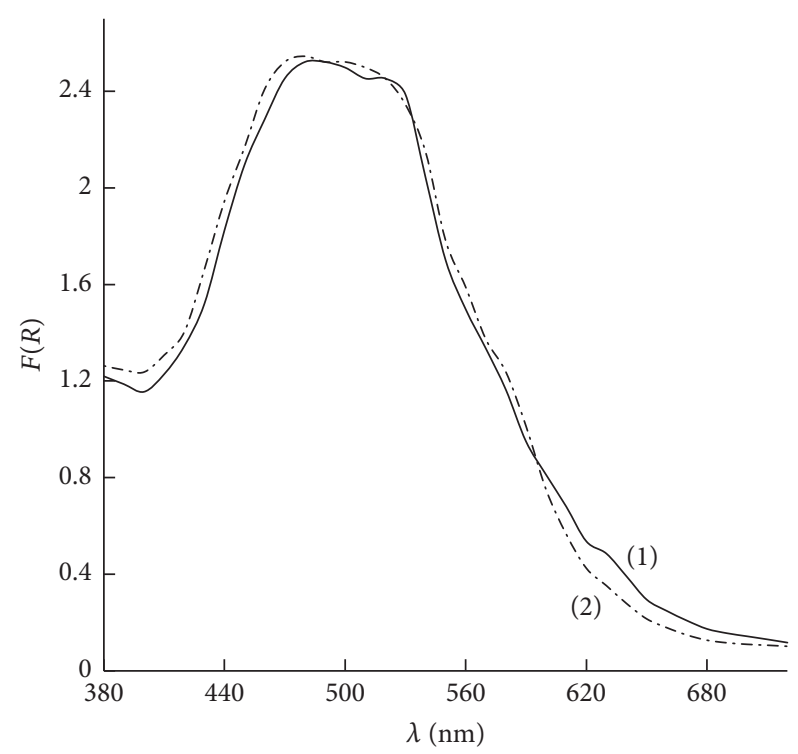

Figure 6: Diffuse reflectance spectra of the surface complexes after $\mathrm{Fe}(\mathrm{III})$ (1) and $\mathrm{Fe}(\mathrm{II})$ (2) sorption by $\mathrm{SiO}_{2}$-PHMG-Tiron sorbent (pH: 3.0 (1), $6.2(2), C_{\mathrm{Fe}}=0.5 \mu \mathrm{g} \mathrm{mL}^{-1} ; \mathrm{V}=10 \mathrm{~mL}, 0.100 \mathrm{~g}$ of the sorbent).

values of sorption capacity of $\mathrm{SiO}_{2}$-PHMG-Tiron sorbent were obtained for Fe(II) (Figure 5, curves (3), (4)). The data indicate that during $\mathrm{Fe}$ (III) and $\mathrm{Fe}$ (II) sorption complexes with the ratio Fe:Tiron $\sim 1: 3$ are mainly formed on the surface of the sorbents with different surface concentration of Tiron.

During Fe(III) sorption at $\mathrm{pH}$ 2.5-4.0 the sorbent surface acquired a red-lilac color. The DRS was a wide band with slightly expressed maxima at 480 and $510 \mathrm{~nm}$ (Figure 6, spectrum (1)). It is known that in aqueous solutions Fe(III) forms complexes with Tiron with the stoichiometry $1: 1,1: 2$, or $1: 3[25,26]$. Blue complex FeL $\left(\lambda_{\max }=665 \mathrm{~nm}\right)$ is formed at $\mathrm{pH}<3.5$, violet complex $\mathrm{FeL}_{2}\left(\lambda_{\max }=553 \mathrm{~nm}\right)$ is formed in the $\mathrm{pH}$ range of 3.5-6.5, and red-lilac complex $\mathrm{FeL}_{3}\left(\lambda_{\max }=\right.$ $480 \mathrm{~nm}$ ) is formed at $\mathrm{pH} \geq 6.5$.

After comparison of the maxima in the DRS of Fe(III) surface complexes with the maxima of their absorption spectra in aqueous solutions it could be assumed that complexes of $\mathrm{Fe}(\mathrm{III})$ with Tiron with the composition $\mathrm{FeL}_{3}$ are mainly formed on the surface of the $\mathrm{SiO}_{2}$-PHMG-Tiron sorbent. $\mathrm{FeL}_{3}$ complex is formed at the $\mathrm{pH}$ values that are characteristic for $\mathrm{FeL}$ and $\mathrm{FeL}_{2}$ complexes formation in solutions because $\mathrm{SiO}_{2}$-PHMG surface promotes an additional coordination of $\mathrm{FeL}$ and $\mathrm{FeL}_{2}$ surface complexes with Tiron molecules.

Similar shift of $\mathrm{FeL}_{3}$ complex formation in acid area with expended $\mathrm{pH}$ range of its formation up to 4-8 was observed during interaction of $\mathrm{Fe}(\mathrm{III})$ with Tiron on the surface of anion-exchange resin Amberlyst A-27 [29].

During $\mathrm{Fe}(\mathrm{II})$ sorption in the $\mathrm{pH}$ range of 6.0-7.5 at both presence and absence of $0.001-0.1 \mathrm{M}$ hydroxylamine solution the surface of $\mathrm{SiO}_{2}$-PHMG-Tiron sorbent acquired a red-lilac color. DRS of the sorbent after Fe(II) sorption from solutions with $\mathrm{pH}$ 6.0-7.5 was identical to DRS of the sorbent after $\mathrm{Fe}(\mathrm{III})$ sorption at $\mathrm{pH} 2.5-4.0$ and had slightly expressed maxima at 480 and $510 \mathrm{~nm}$ (Figure 6, spectrum (2)).

Intensities of the bands in DRS of the sorbents after sorption of $\mathrm{Fe}$ (III) and $\mathrm{Fe}$ (II) were equal, which is evidence of identity of the surface complexes composition.

Maximum intensity of the sorbent color was observed in the $\mathrm{pH}$ range coinciding with the $\mathrm{pH}$ ranges of the quantitative extraction of $\mathrm{Fe}$ (III) and Fe(II) (Figure 4, curves (3), (4)).

3.3. Study of Fe(III) Complexes with Tiron on the Surface of $\mathrm{SiO}_{2}-\mathrm{PHNG}$-Tiron Sorbent and in Aqueous Solutions Using $E P R$. In order to determine the oxidation state of iron in its complexes with Tiron using EPR method at $77 \mathrm{~K}$ the following objects were studied:

(i) $\mathrm{SiO}_{2}$-PHMG-Tiron sorbents after $\mathrm{Fe}(\mathrm{III})$ and $\mathrm{Fe}(\mathrm{II})$ sorption at various $\mathrm{pH}$ values;

(ii) solutions after mixing of Fe(III) and Fe(II) solutions with Tiron at various $\mathrm{pH}$ values.

In the low-field region of EPR spectra of $\mathrm{SiO}_{2}$-PHMGTiron sorbent after $\mathrm{Fe}(\mathrm{III})$ and $\mathrm{Fe}(\mathrm{II})$ sorption an intensive signal with $g=4.27$ was observed (Figure 7, curves (1), (2)). Similar EPR signal was observed for Fe(III) complexes with desferrioxamine [30]. EPR spectra of $\mathrm{SiO}_{2}$-PHMG-Tiron after $\mathrm{Fe}$ (III) and $\mathrm{Fe}$ (II) sorption in optimum conditions were identical, which is an evidence of the oxidation state of iron within the surface complex +3 . On the basis of EPR data it can be concluded that during interaction of Fe(II) with Tiron at $\mathrm{pH}$ 6.0-7.5 on the surface of $\mathrm{SiO}_{2}$-PHMG-Tiron it is oxidized up to $\mathrm{Fe}(\mathrm{III})$.

Even though Fe(III) complexes with Tiron of different composition (Fe: Tiron $=1: 1,1: 2,1: 3$ ) are formed in solution at different $\mathrm{pH}$ values, EPR spectra of solutions after mixing $\mathrm{Fe}(\mathrm{III})$ and Tiron solutions (Figure 7, curve (3)) in the $\mathrm{pH}$ range of 3.0-9.0 are identical to each other and to EPR spectra of $\mathrm{Fe}$ (III) complexes, which are formed on the surface of $\mathrm{SiO}_{2}$-PHMG-Tiron sorbent and characterized by intensive 


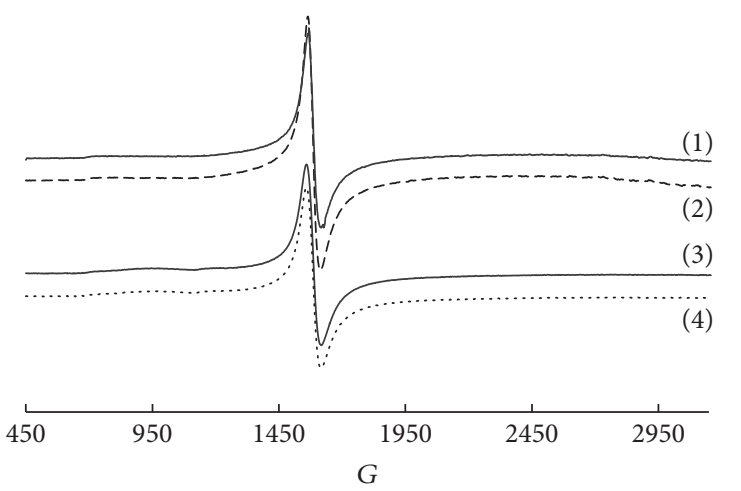

FIGURE 7: EPR spectra of Fe(III) complexes formed on the surface of $\mathrm{SiO}_{2}$-PHMG-Tiron sorbent during the sorption of $\mathrm{Fe}$ (III) (1) and $\mathrm{Fe}(\mathrm{II})(2)$ and $\mathrm{Fe}(\mathrm{III})$ complexes with Tiron in aqueous solution after interaction between $\mathrm{Fe}(\mathrm{III})$ (3) or Fe(II) (4) and Tiron (pH: 3.0 (1), $6.2(2)$, and $8.0(3,4), 0.200 \mathrm{~g}$ of the sorbent $(1,2)$, and $C_{\mathrm{Fe}}=20 \mu \mathrm{g}$ per $0.200 \mathrm{~g}$ of the sorbent $(1,2), 0.36 \mathrm{mM}(3,4) ; C_{\text {Tiron }}=16 \mu \mathrm{mol} \mathrm{g}^{-1}$ $(1,2) ; 1.6 \mathrm{mM}(3,4))$.

EPR signal with $g=4.27$. EPR spectra of the solutions after mixing Fe(II) and Tiron solutions at pH 6.0-9.0 are also characterized by intensive signal with $g=4.27$ (Figure 7 , curve (4)). The shape of the spectra and EPR signals intensities are identical for the solutions obtained by mixing of the same concentrations of Fe(III) or Fe(II) with Tiron. Even in the presence of $0.001-0.1 \mathrm{M}$ hydroxylamine in the solution $\mathrm{Fe}(\mathrm{II})$ formed complex with Tiron at $\mathrm{pH}$ 6.0-7.5 having intensive signal with $g=4.27$ in EPR spectrum. The identity of ESR spectra in this case indicates that hydroxylamine does not prevent oxidation of iron (II) during complexation with Tiron at $\mathrm{pH} 6.0-7.5$.

Thus, from the EPR data it can be concluded that during interaction of $\mathrm{Fe}$ (II) with Tiron both in solution and on the surface of the sorbent it is oxidized to Fe(III). Both dissolved in water oxygen and the reagent itself can be an oxidant of $\mathrm{Fe}(\mathrm{II})$ [13]. The rate of $\mathrm{Fe}(\mathrm{II})$ oxidation increases with the rising of degree of saturation of solution with oxygen at $\mathrm{pH}>$ 5 in the presence of acetate ions; that coincides with the area of its quantitative extraction by $\mathrm{SiO}_{2}$-PHMG-Tiron.

The identity of EPR spectra of $\mathrm{SiO}_{2}$-PHMG-Tiron sorbent after $\mathrm{Fe}(\mathrm{III})$ and $\mathrm{Fe}(\mathrm{II})$ sorption is the evidence of oxidation level of iron within the surface complex +3 ; and the identity of color and DRS of Fe(III) complexes on the surface of $\mathrm{SiO}_{2}$-PHMG-Tiron sorbent is the evidence of identical composition of the surface complexes.

\subsection{Sorption-Photometric Determination of $\mathrm{Fe}$ (III) and $\mathrm{Fe}(\mathrm{II})$} Using $\mathrm{SiO}_{2}-\mathrm{PHMG}$-Tiron. As the iron content on the sorbent surface increased, the intensity of sorbent color increased proportionally; and shape of DRS and position of its maxima did not depend on iron concentration. Formation of intensively colored complexes on $\mathrm{SiO}_{2}$-PHMG-Tiron surface was used for development of the following procedures:

(i) Sorption-photometric determination of $\mathrm{Fe}(\mathrm{III})$ and $\mathrm{Fe}(\mathrm{II})$
TABLE 1: RSD for determination of iron concentration per $0.1 \mathrm{~g}$ of $\mathrm{SiO}_{2}$-PHMG-Tiron $(n=5)$.

\begin{tabular}{lcc}
\hline Added, $\mu \mathrm{g}$ & Found, $\mu \mathrm{g}$ & RSD, $\%$ \\
\hline 0.10 & $0.09 \pm 0.01$ & 9.1 \\
0.20 & $0.21 \pm 0.02$ & 6.2 \\
0.50 & $0.50 \pm 0.02$ & 4.0 \\
1.0 & $1.00 \pm 0.04$ & 3.2 \\
5.0 & $5.1 \pm 0.3$ & 4.5 \\
\hline
\end{tabular}

(ii) Sorption-photometric determination of total iron in natural waters.

The analytical characteristics of the developed method such as the limit of detection, linear range, and correlation coefficient were obtained by processing standard solutions under optimum conditions. A linear calibration graph was obtained for the determination of iron (II) under the proposed experimental conditions. The calibration equations in coordinates $\Delta F(R)-c$, where $c$ is iron content ( $\mu$ g per $0.100 \mathrm{~g}$ of the sorbent), were as follows:

(i) $\Delta F(R)=(0.593 \pm 0.003) c\left(R^{2}=0.999\right)$ for $\mathrm{Fe}(\mathrm{II})$ sorption.

(ii) $\Delta F(R)=(0.596 \pm 0.003) c\left(R^{2}=0.998\right)$ for $\mathrm{Fe}(\mathrm{III})$ sorption.

The detection limit for iron determination calculated using $3 \mathrm{~s}$-criterion was $0.05 \mu \mathrm{g}$ per $0.100 \mathrm{~g}$ of the sorbent. The calibration graphs were linear up to $20.0 \mu \mathrm{g}$ of Fe per $0.100 \mathrm{~g}$ of the sorbent. The relative standard deviation $(\mathrm{RSD}=(s / \bar{x})$ $\times 100 \%)$ in the determination of more than $0.2 \mu \mathrm{g}$ of Fe per $0.100 \mathrm{~g}$ of the sorbent was less than $6.2 \%, n=5$ (Table 1 ). The detection limits, the range of linearity of calibration graphs, and RSD are independent of initial oxidation level of iron.

$\mathrm{SiO}_{2}$-PHMG-Tiron sorbent is characterized by good kinetics. As the ratio volume of solution to the sorbent mass $(\mathrm{V}: \mathrm{m})$ rises from $10^{2}$ to $10^{3}$, and the time of attainment of sorption equilibrium did not exceed $10 \mathrm{~min}$. An increase of volume of solution from 10 to $100 \mathrm{~mL}$ (using $0.100 \mathrm{~g}$ of the sorbent) leads to decrease of the relative detection limit from $5 \mathrm{ng} \mathrm{mL}^{-1}$ to $0.5 \mathrm{ng} \mathrm{mL}^{-1}$.

3.5. Effect of Potentially Interfering Ions. Solutions containing $\mathrm{Fe}$ (II) or $\mathrm{Fe}$ (III) $\left(0.1 \mu \mathrm{g} \mathrm{mL}^{-1}\right)$ and other ions were prepared and the developed procedure was applied in order to determine the selectivity of the sorbent.

Sorption preconcentration from solution at $\mathrm{pH} 3.0$ and sorption-photometric determination of $\mathrm{Fe}$ (III) was not affected by the following cations (in multiple amounts): $\mathrm{Na}^{+}$, $\mathrm{K}^{+}, \mathrm{Sr}^{2+}, \mathrm{Ca}^{2+}, \mathrm{Mg}^{2+}(1000), \mathrm{Pb}^{2+}, \mathrm{Ni}^{2+}, \mathrm{Zn}^{2+}, \mathrm{Hg}^{2+}$ (500), $\mathrm{Bi}^{3+},(500), \mathrm{Sn}^{2+}, \mathrm{Al}^{3+}, \mathrm{Cr}^{3+}$, and $\mathrm{Cu}^{2+}$ (100).

Sorption preconcentration from solution at $\mathrm{pH} \quad 6.2$ and sorption-photometric determination of $\mathrm{Fe}(\mathrm{II})$ was not affected by the following cations (in multiple amounts): $\mathrm{Na}^{+}$, $\mathrm{K}^{+}, \mathrm{Sr}^{2+}, \mathrm{Ca}^{2+}, \mathrm{Mg}^{2+}, \mathrm{Pb}^{2+}$ (1000), $\mathrm{Ni}^{2+}$ (500), $\mathrm{Zn}^{2+}$ (250), $\mathrm{Bi}^{3+}, \mathrm{Hg}^{2+}$ (100), $\mathrm{Sn}^{2+}, \mathrm{Al}^{3+}(50), \mathrm{Cr}^{3+}$, and $\mathrm{Cu}^{2+}$ (10). Salt background up to $50 \mathrm{gL}^{-1}$ for $\mathrm{NaCl}, 5 \mathrm{gL}^{-1}$ for $\mathrm{Na}_{2} \mathrm{SO}_{4}$, 
TABLE 2: Results of Fe(III) and Fe(II) determination in model solutions using minicolumn $(n=5)$.

\begin{tabular}{|c|c|c|c|c|c|}
\hline \multicolumn{2}{|c|}{ Added, $\mu \mathrm{g}$} & \multicolumn{2}{|c|}{ Length of colored zone, $\mathrm{mm}$} & \multicolumn{2}{|c|}{ Found, $\mu \mathrm{g}$} \\
\hline $\mathrm{Fe}(\mathrm{III})$ & $\mathrm{Fe}(\mathrm{II})$ & $\mathrm{Fe}(\mathrm{III})$ & $\mathrm{Fe}(\mathrm{II})$ & $\mathrm{Fe}(\mathrm{III})$ & $\mathrm{Fe}(\mathrm{II})$ \\
\hline- & 5.0 & - & $10 \pm 1$ & - & $5.0 \pm 0.5$ \\
\hline 5.0 & - & $10 \pm 1$ & - & $5.0 \pm 0.5$ & - \\
\hline 1.0 & 5.0 & $2 \pm 1$ & $10 \pm 1$ & $1.0 \pm 0.5$ & $5.0 \pm 0.5$ \\
\hline 2.0 & 5.0 & $4 \pm 1$ & $10 \pm 1$ & $2.0 \pm 0.5$ & $5.0 \pm 0.5$ \\
\hline 5.0 & 1.0 & $10 \pm 1$ & $2 \pm 1$ & $5.0 \pm 0.5$ & $1.0 \pm 0.5$ \\
\hline 5.0 & 2.0 & $10 \pm 1$ & $4 \pm 1$ & $5.0 \pm 0.5$ & $2.0 \pm 0.5$ \\
\hline 5.0 & 5.0 & $10 \pm 1$ & $10 \pm 1$ & $5.0 \pm 0.5$ & $5.0 \pm 0.5$ \\
\hline
\end{tabular}

TABLE 3: Results of Fe(III) and Fe(II) determination in well waters $(n=5)$.

\begin{tabular}{|c|c|c|c|c|c|c|c|}
\hline \multirow{3}{*}{ Sample } & \multicolumn{6}{|c|}{ Found, $\mu \mathrm{g} \mathrm{mL}^{-1}$} & \multirow{3}{*}{$\begin{array}{l}\text { Total Fe, } \\
\mu \mathrm{g} \mathrm{mL} L^{-1}\end{array}$} \\
\hline & \multicolumn{3}{|c|}{$\mathrm{Fe}(\mathrm{III})$} & \multicolumn{3}{|c|}{$\mathrm{Fe}(\mathrm{II})$} & \\
\hline & $0.5 \mathrm{~h}$ & $6 \mathrm{~h}$ & $24 \mathrm{~h}$ & $0.5 \mathrm{~h}$ & $6 \mathrm{~h}$ & $24 \mathrm{~h}$ & \\
\hline Well water number 1 & 0 & 0.14 & * & 0.18 & 0.05 & 0 & 0.18 \\
\hline Well water number 2 & 0.1 & 1.0 & * & 1.7 & 0.6 & 0.1 & 1.8 \\
\hline
\end{tabular}

* Iron (III) hydroxide precipitation.

and $25 \mathrm{~g} \mathrm{~L}^{-1}$ for $\mathrm{Na}_{2} \mathrm{SO}_{3}$ did not prevent $\mathrm{Fe}(\mathrm{III})$ and $\mathrm{Fe}(\mathrm{II})$ preconcentration and determination.

Selectivity of Fe(III) determination is higher compared to $\mathrm{Fe}(\mathrm{II})$ determination because $\mathrm{Fe}$ (III) complexation with Tiron occurs in more acidic area, where no interaction with other metal ions (forming complexes at $\mathrm{pH}>4$ ) with Tiron takes place $[31,32]$.

3.6. Sorption Separation and Determination of $\mathrm{Fe}(\mathrm{III})$ and $\mathrm{Fe}(\mathrm{II})$. Dependence of Fe(II) and Fe(III) quantitative extraction by $\mathrm{SiO}_{2}-\mathrm{PHMG}$-Tiron sorbent versus $\mathrm{pH}$ and formation of intensively colored $\mathrm{Fe}$ (III) surface complexes was used for sequential sorption isolation and separate determination of $\mathrm{Fe}(\mathrm{III})$ and $\mathrm{Fe}$ (II) from one sample of the solution.

During sorption in the batch mode Fe(III) content was found almost 1.5 times higher than it was added and Fe(II) content 1.5 times lower than it was added. But the total $\mathrm{Fe}$ (III) and Fe(II) content were equal to when they were added. Overestimated results of Fe(III) determination and underestimated results of $\mathrm{Fe}$ (II) determination are explained by saturation of solution by atmospheric oxygen during intensive stirring at $\mathrm{pH} 3$, the optimum conditions for $\mathrm{Fe}(\mathrm{III})$ extraction, and $\mathrm{Fe}(\mathrm{II})$ is oxidized up to $\mathrm{Fe}(\mathrm{III})$.

Sorption in flow analysis using minicolumn allows eliminating saturation of solution by atmospheric oxygen and accomplishing both separation and determination of Fe(II) and Fe(III) from one sample of solution by the length of colored zone of the sorbent using system represented on Figure 1. The sorbent in minicolumns became red-lilac color.

The length of colored zone of the sorbents after passing $\mathrm{Fe}$ (III) and Fe(II) solutions of equal concentrations was equal, and it increased proportionally to their content in solution. The calibration function for $\mathrm{Fe}$ (II) and Fe(III) determination by the length of the colored zone $(l)$ was as follows: $l(\mathrm{~mm})=$ $2 c \pm 1$, where $c$ is iron content in minicolumn, $\mu \mathrm{g}$. Iron content determined by the length of the colored zone in the model solution is represented in Table 2. An increase of the flow rate of the solution from 0.5 to $3.0 \mathrm{~mL} \mathrm{~min}^{-1}$ led to the erosion of the colored zone.

Procedure for the separate determination of Fe(III) and $\mathrm{Fe}$ (II) by the length of the colored zone in minicolumn was used for the analysis of well water during storage: in $30 \mathrm{~min}$, $6 \mathrm{~h}$, and $24 \mathrm{~h}$ after sampling. Obtained results are represented in Table 3.

In well waters that are of high iron content $\left(>2 \mathrm{mg} \mathrm{L}^{-1}\right)$ and free of organic compounds (humic and fulvic acids) in contact with air oxidation of $\mathrm{Fe}$ (II) to $\mathrm{Fe}$ (III) proceeds with subsequent precipitation of slightly soluble iron (III) hydroxide. Fe(II) content was determined in well waters with high iron content after separation of iron (III) hydroxide sediment using membrane filter.

The data represented in Table 3 shows that in the cases of low iron content in natural waters the results of sorptionphotometric determination of total content of $\mathrm{Fe}(\mathrm{III})$ and $\mathrm{Fe}(\mathrm{II})$ are in agreement with the results of total iron determination using ICP-OES.

3.7. Determination of Total Iron in Natural Waters. In order to decompose metal complexes with organic compounds natural waters were boiled with nitric acid. Organic complexes of iron were destroyed, and iron was oxidized up to $\mathrm{Fe}(\mathrm{III})$ as a result, which was hydrolyzed forming poorly soluble compounds. Despite higher selectivity of sorptionphotometric determination of Fe(III) at $\mathrm{pH} \mathrm{3.0,} \mathrm{in} \mathrm{order} \mathrm{to}$ determine the total iron content it is reasonable to reduce $\mathrm{Fe}$ (III) to $\mathrm{Fe}(\mathrm{II})$, because it is less hydrolyzed in aqueous solutions and does not form poorly soluble compounds. Hydroxylamine is preferred to be used as the reducing agent because its presence does not affect the formation of the surface complex of Fe(III) with Tiron.

Developed procedure was applied for total iron determination in waste waters (samples number 1 and number 2), 
TABLE 4: Results of total iron determination in natural and mineral waters $(n=5)$.

\begin{tabular}{lccc}
\hline Sample & & Found Fe, $\mathrm{mg} \mathrm{L}^{-1}$ & \\
& Corption-photometric method & $2.0 \pm 0.5^{\mathrm{a}}$ & ICP-AES \\
\hline Waste water No. 1 & $1.8 \pm 0.1^{\mathrm{a}}$ & $2.0 \pm 0.5^{\mathrm{a}}$ & $1.6 \pm 0.1$ \\
Waste water No. 2 & $2.1 \pm 0.1^{\mathrm{a}}$ & $0.5 \pm 0.5^{\mathrm{a}}$ & $2.1 \pm 0.1$ \\
River water & $0.60 \pm 0.04^{\mathrm{a}}$ & $\sim 0.05^{\mathrm{a}}$ & $0.60 \pm 0.03$ \\
Mineral water «Uchumskaya» & $0.045 \pm 0.008^{\mathrm{a}}$ & - & $0.050 \pm 0.007$ \\
Mineral water «Zagorie» & $14.4 \pm 0.7^{\mathrm{b}}$ & $15.0 \pm 0.6$ \\
\hline
\end{tabular}

${ }^{\mathrm{a}}$ Sample volume: $5 \mathrm{~mL} .{ }^{\mathrm{b}}$ Sample volume: $1 \mathrm{~mL}$.

taken in various districts of Krasnoyarsk city; river water; drink waters: low mineralized water "Uchumskaya" and highly mineralized water "Zagorie" produced in Krasnoyarsk Krai. The accuracy of procedure was confirmed by ICP-OES method. The results of iron determination are represented in Table 4.

An intensely colored zone appeared when a sample was passed through a minicolumn filled with a sorbent. Dependence of the length of colored zone of the sorbent on iron content was used for total iron determination in natural waters (Table 4).

\section{Conclusion}

$\mathrm{SiO}_{2}$-PHMG-Tiron sorbent proposed for preconcentration, separation, and determination of $\mathrm{Fe}(\mathrm{II})$ and $\mathrm{Fe}(\mathrm{III})$ is characterized by simplicity of synthesis from widespread and available reagents and does not require complex and expensive equipment. The sorbent allows quantitative sequential isolation and determination of $\mathrm{Fe}$ (II) and $\mathrm{Fe}$ (III) from one sample of water. Developed procedures are comparable to FAAS and ICP-OES in terms of detection limits. Application of minicolumn filled with $\mathrm{SiO}_{2}$-PHMG-Tiron sorbent allows rapid and accurate visual estimation of $\mathrm{Fe}$ (II) and $\mathrm{Fe}$ (III) content in natural waters. Procedure of iron determination by the length of colored zone in minicolumn does not require equipment and can be applied for iron determination in natural waters in the field.

\section{Conflicts of Interest}

The authors declare that they have no conflicts of interest.

\section{Acknowledgments}

This study was supported by the Ministry of Education and Science of the Russian Federation (Project no. 4.6343.2017 for Siberian Federal University).

\section{References}

[1] S. Pehkonen, "Determination of the oxidation states of iron in natural waters A Review," Analyst, vol. 120, no. 11, pp. 2655-2663, 1995.

[2] Z. Marczenko and M. Balcerzak, Separation, Preconcentration, and Spectrophotometry in Inorganic Analysis, Elsevier, Amsterdam, Netherlands, 2001.
[3] M. Kass and A. Ivaska, "Spectrophotometric determination of iron(III) and total iron by sequential injection analysis technique," Talanta, vol. 58, no. 6, pp. 1131-1137, 2002.

[4] S. O. Pehkonen, Y. Erel, and M. R. Hoffmann, "Simultaneous spectrophotometric measurement of $\mathrm{Fe}(\mathrm{II})$ and $\mathrm{Fe}$ (III) in atmospheric water," Environmental Science \& Technology, vol. 26, no. 9, pp. 1731-1736, 1992.

[5] M. C. Da Cunha Areias, L. H. S. Ávila-Terra, I. Gaubeur, and M. E. V. Suárez-Iha, "A new simultaneous spectrophotometric method for determination of iron(II) and iron(III) in natural waters," Spectroscopy Letters, vol. 34, no. 3, pp. 289-300, 2001.

[6] A. de Assis Gonsalves, C. R. M. Araújo, C. X. Galhardo, M. O. F. Goulart, and F. C. de Abreu, "Hydralazine hydrochloride: An alternative complexometric reagent for total iron spectrophotometric determination," American Journal of Analytical Chemistry, vol. 2, no. 11, pp. 776-782, 2011.

[7] M. Hoshino, H. Yasui, H. Sakurai, T. Yamaguchi, and Y. Fujita, "Improved spectrophotometric determination of total iron and iron (III) with o-hydroxyhydroquinonephthalein and their characterization," Yakugaku Zasshi, vol. 131, no. 7, pp. 1095-1101, 2011.

[8] J. Paluch, J. Kozak, M. Wieczorek et al., "Novel approach to twocomponent speciation analysis. Spectrophotometric flow-based determinations of $\mathrm{Fe}(\mathrm{II}) / \mathrm{Fe}(\mathrm{III})$ and $\mathrm{Cr}(\mathrm{III}) / \mathrm{Cr}(\mathrm{VI})$," Talanta, vol. 171, pp. 275-282, 2017.

[9] J. Kozak, J. Paluch, A. Węgrzecka et al., "Single peak parameters technique for simultaneous measurements: Spectrophotometric sequential injection determination of $\mathrm{Fe}(\mathrm{II})$ and $\mathrm{Fe}(\mathrm{III})$, Talanta, vol. 148, pp. 626-632, 2016.

[10] B. Oktavia, L. W. Lim, and T. Takeuchi, "Simultaneous determination of $\mathrm{Fe}$ (III) and $\mathrm{Fe}(\mathrm{II})$ ions via complexation with salicylic acid and 1,10-phenanthroline in microcolumn ion chromatography," Analytical Sciences, vol. 24, no. 11, pp. 1487-1492, 2008.

[11] S. Pozdniakova, A. Padarauskas, and G. Schwedt, "Simultaneous determination of iron(II) and iron(III) in water by capillary electrophoresis," Analytica Chimica Acta, vol. 351, no. 1-3, pp. 41-48, 1997.

[12] J. Zolgharnein, H. Abdollahi, D. Jaefarifar, and G. H. Azimi, "Simultaneous determination of Fe(II) and Fe(III) by kinetic spectrophotometric H-point standard addition method," Talanta, vol. 57, no. 6, pp. 1067-1073, 2002.

[13] S. Abe, T. Saito, and M. Suda, "Simultaneous determination of iron(II) and iron(III) in aqueous solution by kinetic spectrophotometry with tiron," Analytica Chimica Acta, vol. 181, no. C, pp. 203-209, 1986.

[14] B. Haghighi and A. Safavi, "Simultaneous flow injection determination of iron(II) and iron(III) with opto-electrochemical detection," Analytica Chimica Acta, vol. 354, no. 1-3, pp. 43-50, 1997. 
[15] Y. Chen, S. Feng, Y. Huang, and D. Yuan, "Redox speciation analysis of dissolved iron in estuarine and coastal waters with on-line solid phase extraction and graphite furnace atomic absorption spectrometry detection," Talanta, vol. 137, pp. 25-30, 2015.

[16] J. L. A. Miranda, R. B. R. Mesquita, A. Nunes, M. Rangel, and A. O. S. S. Rangel, "Iron speciation in natural waters by sequential injection analysis with a hexadentate 3-hydroxy-4-pyridinone chelator as chromogenic agent," Talanta, vol. 148, pp. 633-640, 2016.

[17] R. Suárez, R. B. R. Mesquita, M. Rangel, V. Cerdâ, and A. O. S. S. Rangel, "Iron speciation by microsequential injection solid phase spectrometry using 3-hydroxy-1(H)-2-methyl-4pyridinone as chromogenic reagent," Talanta, vol. 133, pp. 1520, 2015.

[18] Sarenqiqige, A. Maeda, and K. Yoshimura, "Determination of trace iron in the boiler water used in power generation plants by solid-phase spectrophotometry," Analytical Sciences, vol. 30, no. 10, pp. 1013-1017, 2014.

[19] O. Y. Nadzhafova, M. V. Drozdova, E. V. Nebesnaya, and V. B. Ishchenko, "Optimization and use of composite coatings based on silicon oxide and polyvinylsulfonic acid for the adsorption-spectrophotometric determination of iron(II) and zinc(II) phenanthrolinates," Journal of Analytical Chemistry, vol. 62, no. 12, pp. 1136-1142, 2007.

[20] N. A. Gavrilenko and O. V. Mokhova, "Sorption-spectrophotometric determination of iron(II, III) with the use of organic reagents immobilized in a polymethacrylate matrix," Journal of Analytical Chemistry, vol. 63, no. 11, pp. 1038-1043, 2008.

[21] M. A. Kassem and A. S. Amin, "Spectrophotometric determination of iron in environmental and food samples using solid phase extraction," Food Chemistry, vol. 141, no. 3, pp. 1941-1946, 2013.

[22] Y. Chen, C.-M. Ding, T.-Z. Zhou, and D.-Y. Qi, "Organic solvent-soluble Membrane Filters for the preconcentration and spectrophotometric determination of iron(II) traces in water with Ferrozine," Fresenius' Journal of Analytical Chemistry, vol. 363, no. 1, pp. 119-120, 1999.

[23] B. K. Puri and S. Balani, "Preconcentration of iron (III), cobalt (II) and copper (II) nitroso-R complexes on tetradecyldimethylbenzylammonium iodide-naphthalene adsorbent," Talanta, vol. 42, no. 3, pp. 337-344, 1995.

[24] N. Pourreza, S. Rastegarzadeh, A. R. Kiasat, and H. Yahyavi, "Spectrophotometric determination of iron(II) after solid phase extraction of its 2,2l bipyridine complex on silica gelpolyethylene glycol," Journal of Spectroscopy, vol. 1, no. 1, Article ID 548345, 2013.

[25] W. A. E. McBryde, "Spectrophotometric reexamination of the spectra and stabilities of the iron (III)-tiron complexes," Canadian Journal of Chemistry, vol. 42, pp. 1917-1927, 1964.

[26] M. J. Sever and J. J. Wilker, "Visible absorption spectra of metal-catecholate and metal-tironate complexes," Dalton Transactions, no. 7, pp. 1061-1072, 2004.

[27] O. V. Kuznetsova, V. M. Ivanov, and N. V. Kazennov, "Sorptionspectroscopic determination of iron in the sorbate phase in the form of pyrocatechol-3,5-disulfonate," Moscow University Chemistry Bulletin, vol. 38, pp. 53-56, 1997.

[28] V. Losev, S. Didukh, A. Trofimchuk, and O. Zaporozhets, "Adsorption-photometric and test determination of copper using silica gel sequentially modified with polyhexamethylene guanidine and bathocuproinedisulphonic acid," Adsorption Science \& Technology, vol. 32, no. 6, pp. 443-452, 2014.
[29] M. M. A. Shriadah and K. Ohzekit, "Effect of anion-exchange resin on the formation of iron(III) - Tiron complexes," Analyst, vol. 111, no. 2, pp. 197-200, 1986.

[30] D. Y. Yegorov, A. V. Kozlov, O. A. Azizova, and Y. A. Vladimirov, "Simultaneous determination of $\mathrm{Fe}$ (III) and $\mathrm{Fe}$ (II) in water solutions and tissue homogenates using desferal and 1,10phenanthroline," Free Radical Biology \& Medicine, vol. 15, no. 6, pp. 565-574, 1993.

[31] M. Kumar, D. P. S. Rathore, and A. K. Singh, "Metal ion enrichment with Amberlite XAD-2 functionalized with Tiron: Analytical applications," Analyst, vol. 125, no. 6, pp. 1221-1226, 2000.

[32] T. I. Tikhomirova, S. S. Kubyshev, N. M. Sorokina, and V. A. Goloviznin, "Preconcentration of metal ions on aluminum oxide modified with tiron," Journal of Analytical Chemistry, vol. 66, no. 1, pp. 2-5, 2011. 

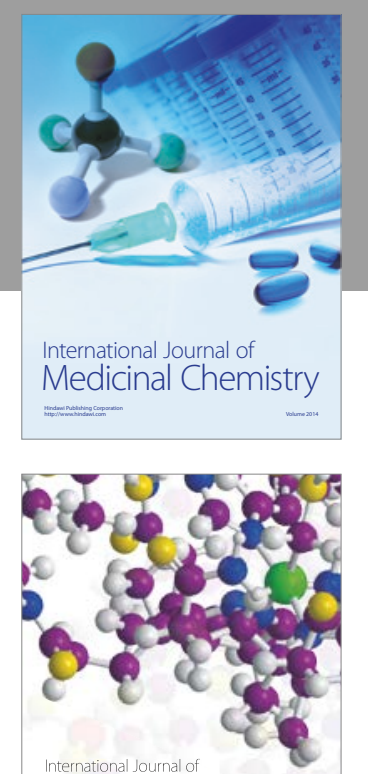

Carbohydrate Chemistry

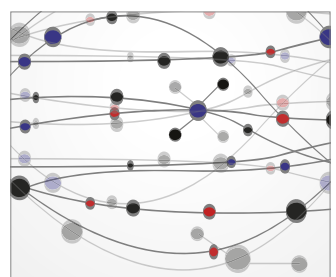

The Scientific World Journal
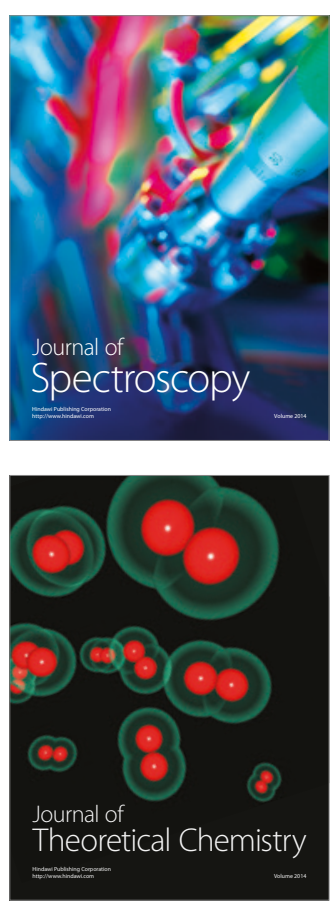
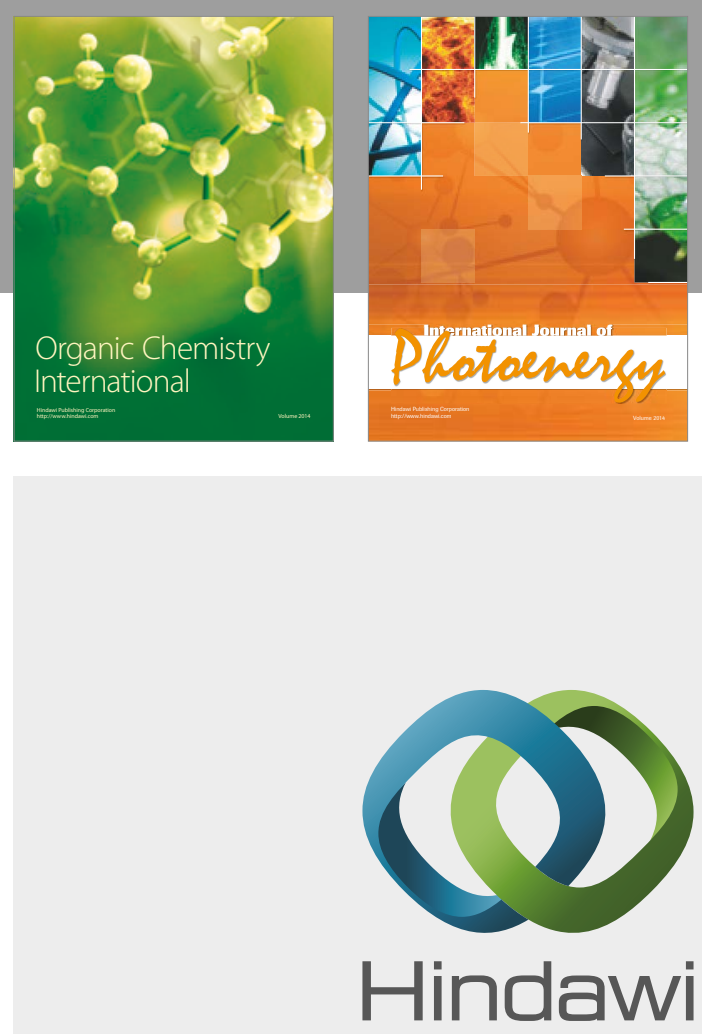

Submit your manuscripts at

https://www.hindawi.com

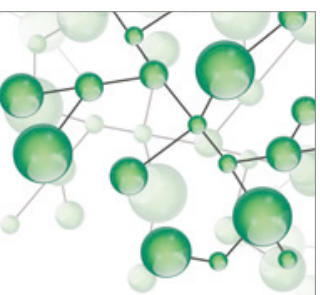

International Journal of

Inorganic Chemistry

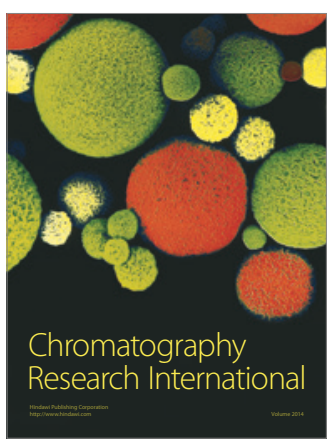

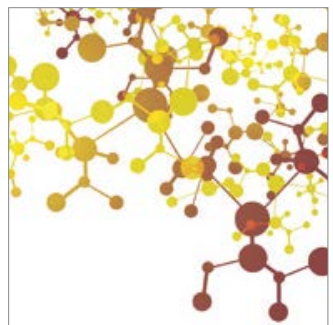

Applied Chemistry
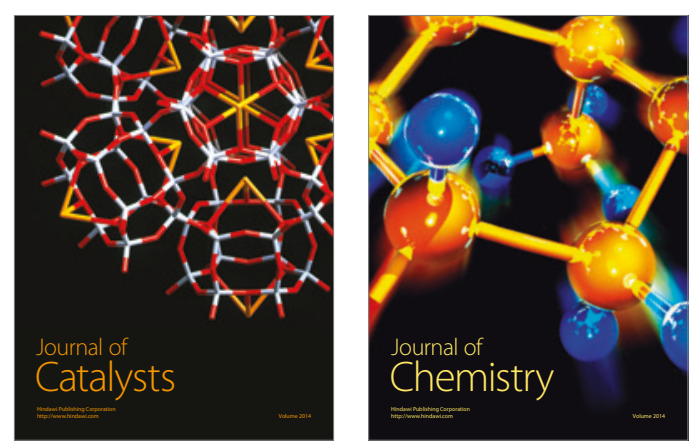
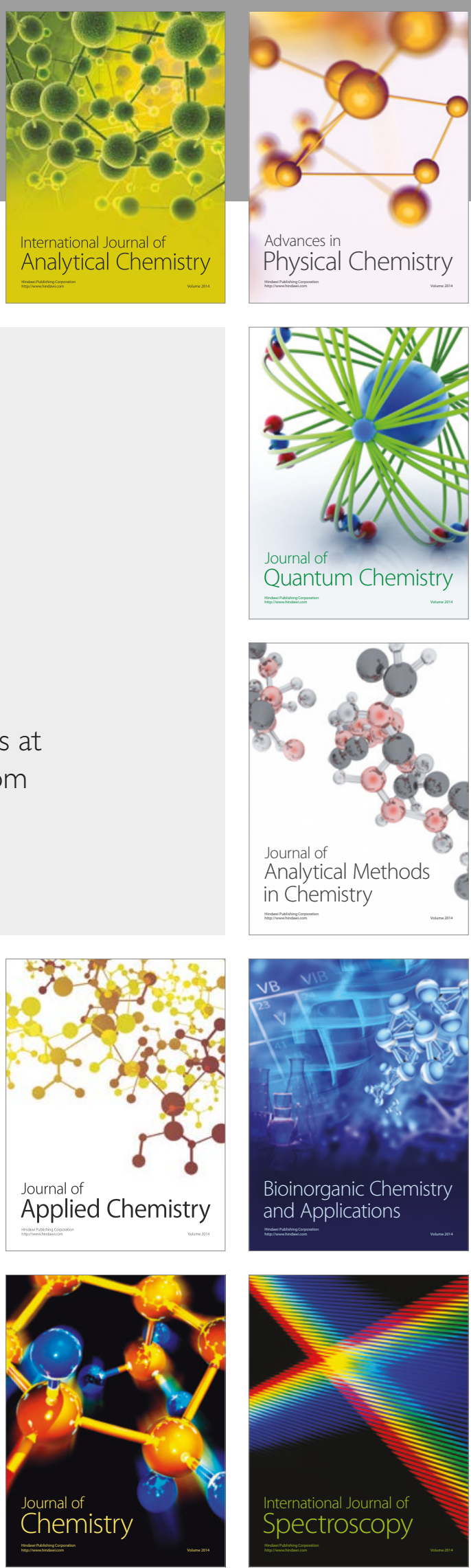